BEATA JAMKA

naukowiec niezależny, Warszawa, Polska • independent researcher, Warsaw, Poland

\title{
Edukacja dla przedsiębiorczości oparta na ekonomii behawioralnej: talent przedsiębiorczy a torowanie
}

\section{Education for Entrepreneurship based on Behavioural Economics: Entrepreneurial Talent and Priming}

Streszczenie: $\mathrm{W}$ artykule podjęto próbę zestawienia modelu przedsiębiorczości rozumianej jako talent $\mathrm{z}$ wybranymi aspektami dynamicznie rozwijających się neuronauk. Celem jest wskazanie potencjału błędów myślenia szybkiego, automatycznego w procesie edukacji przedsiębiorczej. Uwaga została skupiona na zjawiskach torowania, ramowania i zakotwiczenia, które odpowiednio ukierunkowane (thalerowska koncepcja „impulsu”), mogą stymulować przedsiębiorczy sposób myślenia i działania. Zastosowaną metodą badawczą jest modelowanie myślowe oraz analogie oparte na krytycznej analizie literatury z zakresu przedsiębiorczości, neuronauk, statystyki i dydaktyki. Postrzeganie przedsiębiorczości jako talentu uzmysławia powszechność jego występowania (choć na zróżnicowanym poziomie), a zatem też możliwość jego powszechnego rozwijania za pomocą dopasowanych do czasu, potrzeb i sytuacji narzędzi. Natomiast ekonomia behawioralna wskazuje drogi racjonalizowania decyzji ludzi - w odróżnieniu od ekonów - przez wykorzystanie popełnianych przez nich błędów myślenia do konstruowania architektury wyborów opartej na starannie dobranych „impulsach”. Nowością jest integracja obszarów badawczych, skutkująca wskazaniem istoty, wagi i przydatności wzmacniania automatyzmów mentalnych przedsiębiorczego postrzegania sytuacji/otoczenia oraz propozycja przykładowych narzędzi działań.

\begin{abstract}
The article attempts to confront the model of entrepreneurship understood as a talent with selected findings of the dynamically developing neurosciences research. The aim of the article is to indicate the potential of human mind's biases when thinking fast (automatically) in entrepreneurial education process. The attention is focused on priming, framing and anchoring effects which adequately directed (Thaler's concept of nudging) may stimulate entrepreneurial ways of thinking and performing. The research method used is thought modelling and analogy based on critical analysis of literature from various areas: entrepreneurship, neurosciences, statistics, and didactics. The perception of entrepreneurship as a talent illustrates the universality of its occurrence (though at a different level), and thus the possibility of its widespread development using tools adapted to time, needs and situation. The behavioural economics on the other hand points out ways of humans' - as opposed to econs' - decisions rationalisation through taking advantage of human mind's biases to construct a choice architecture based on well-
\end{abstract}


matched nudges. The novelty added by the analysis is the integration of research areas in the indication of the essence, importance and usefulness of strengthening mental automatisms of entrepreneurial perception of the situation and environment, as well as the proposition of examples of action tools.

Słowa kluczowe: edukacja; ekonomia behawioralna; neuronauka; przedsiębiorczość; talent

Keywords: behavioural economics; education; entrepreneurship; neuroscience; talent

Otrzymano: 22 października 2019

Received: 22 October 2019

Zaakceptowano: 22 marca 2020

Accepted: 22 March 2020

\section{Sugerowana cytacja/Suggested citation:}

Jamka, B. (2020). Edukacja dla przedsiębiorczości oparta na ekonomii behawioralnej: talent przedsiębiorczy i torowanie. Przedsiębiorczość - Edukacja [Entrepreneurship - Education], 16(1), 19-30. doi: $10.24917 / 20833296.161 .2$

\section{Wstęp}

Planowy rozwój i doskonalenie pożądanych zachowań wymagają uprzedniego zdefiniowania kompetencji/atrybutów, które tymi zachowaniami sterują i skutkują. Choć powyższa przyczynowo-skutkowa relacja wydaje się oczywista i prosta, nadal nierozwiązanym problemem pozostaje istota przedsiębiorczości, a w konsekwencji - enumeracja i geneza cech ją konstytuujących. Dyskusje trwają, a w literaturze przedmiotu nieustannie pojawiają się nowe zestawy cech i kompetencji przedsiębiorczych.

$\mathrm{W}$ artykule podjęto próbę odmiennego podejścia do tematu, przez zestawienie modelu przedsiębiorczości rozumianej jako talent $\mathrm{z}$ wybranymi aspektami dynamicznie rozwijającego się dorobku neuronauk. Celem jest wskazanie potencjału błędów myślenia szybkiego, automatycznego w procesie edukacji przedsiębiorczej. Ponieważ człowiek ze swoim mózgiem jest „urządzeniem przenośnym działającym na baterie” (Eagleman, 2012: 94), jego wydajność energetyczna jest kluczowym kryterium funkcjonowania. Zasada oszczędności energii rządzi więc także procesami myślenia, stąd w pierwszej kolejności uruchamiany jest wydajniejszy energetycznie, bo zautomatyzowany system myślenia, który ułatwia i przyspiesza podejmowanie decyzji i działań. Niestety, kosztem automatyzacji są tzw. pułapki myślenia (Kahneman, 2012), czyli różnego rodzaju schematy i uproszczenia w „maszynerii skojarzeniowej”, które ukierunkowują myślenie na wypracowaną rutynę. Zasadniczo stanowią one ułomność myślenia, bo zawężają i zniekształcają rozpatrywane opcje, ale zarazem tworzą potencjał dla konstruowania adekwatnej architektury wyborów (thalerowska koncepcja „impulsu” i libertariańskiego paternalizmu; Thaler, Sunstein, 2017). Ponieważ sygnalizowana problematyka jest bardzo szeroka, uwaga została skupiona wyłącznie na zjawiskach torowania, ramowania i zakotwiczenia, które odpowiednio ukierunkowane mogą stymulować przedsiębiorczy sposób myślenia i działania. Zastosowaną metodą badawczą jest modelowanie myślowe oraz analogie oparte na krytycznej analizie literatury z zakresu przedsiębiorczości, neuronauk, statystyki i dydaktyki.

Podejmując próbę charakterystyki istoty przedsiębiorczości dla dalszych rozważań, warto wyjść od analizy umiejscowienia jej hasła w Słowniku synonimów (Dąbrówka, Geller, Turczyn, 1993: 115-116), stworzonym w tzw. układzie gniazdowym. Słowo „przedsiębiorczość” wchodzi w skład gniazda „rozum” (a. umysł; b. mądrość; c. inteligencja; 
Rycina 1. Przedsiębiorczość i innowacyjność

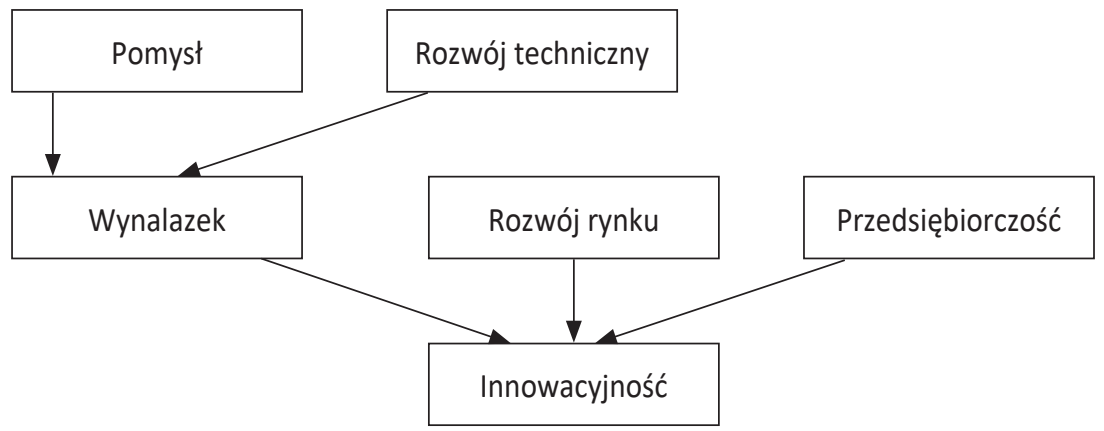

Źródło: Wissema (2005: 18)

d. pomysłowość), w obszarze „inteligencji” (dyplomacja, spryt, bystrość, esprit, przytomność; przenikliwość, czujność, wyczulenie, czułość, ostrość; błyskotliwość, pojętność, lotność; przedsiębiorczość, zaradność, rzutkość, inicjatywa). Takie umieszczenie przedsiębiorczości silnie eksponuje jej związek ze sposobem myślenia, a więc postrzegania świata, opierającym się na sprawczości, a nie - co warte podkreślenia - jej mniejszą lub większą identyfikację z pomysłowością, kreatywnością i innowacyjnością, które to cechy są przedsiębiorcom powszechnie przypisywane. Innowacyjność jest połączeniem wynalazku z przedsiębiorczością, umożliwionym przez adekwatny rozwój rynku, co ilustruje rycina 1.

W modelu J.G. Wissemy przedsiębiorczość jest jednym z trzech niezbędnych, dopełniających się składników innowacyjności (obok wynalazków i rynku). Jest tą składową, która ma moc przekształcania „pomysłu” (wynalazku) i „potrzeby” (popytu rynkowego) w działanie. Z przedstawianej perspektywy przedsiębiorczość ma więc kluczowe znaczenie dla generowania efektu synergicznego w postaci innowacyjności i - w konsekwencji - rozwoju oraz postępu gospodarek i cywilizacji. Dlatego we współczesnym, turbozmiennym otoczeniu, przedsiębiorczość staje się niemal imperatywem funkcjonowania jednostek i ich organizacji, a edukacja dla przedsiębiorczości - istotnym wyzwaniem rozwojowym.

\section{Przedsiębiorczość jako talent}

Talent, zdolności (uzdolnienia), inteligencja, genialność (geniusz) to bazowe pojęcia z zakresu psychologii rozwoju człowieka, determinujące kierunki i instrumentarium działań zarówno w sferze edukacji: zawodowej i ustawicznej (odkrywanie, pielęgnowanie i mobilizowanie), jak i w sferze zarządzania: organizacją i jej pracownikami (identyfikacja, stymulacja i twórcze wykorzystywanie). Literatura przedmiotu dostarcza bogactwa definicji i klasyfikacji wymienionych pojęć, niemniej jednak istnieje dość powszechna zgoda co do tego, iż talent jest swoistym połączeniem uzdolnień:

- urzeczywistniającym się w określonej działalności człowieka dzięki interakcji czynników wewnętrznych i zewnętrznych (Hornowski, 1986),

- stwarzającym możliwości twórczego wykonywania jakiegoś zadania na najwyższym poziomie (Strelau, 1997). 
Zgodnie z koncepcją A. Tannenbauma, talent jest efektem interakcji siedmiu ${ }^{1}$ czynników:

- zdolności ogólnych,

- zdolności kierunkowych/specjalnych,

- czynników środowiskowych, sprzyjających rozwojowi zdolności,

- cech osobowości stymulujących działanie (temperament, emocjonalność, motywacja, koncentracja itd.),

- czynnika przypadku/losowego (odpowiednie miejsce i czas) oraz

- myślenia twórczego

- i aktywności własnej (Tannenbaum, 1984).

Transpozycja wymienionych powyżej czynników talentu na specyficzny talent przedsiębiorczości jest następująca (pogłębione omówienie poszczególnych składowych talentu przedsiębiorczości w: Jamka, 2014):

- zdolności ogólne,

- zdolności kierunkowe/specjalne $\rightarrow$ umiejętność dostrzegania okazji,

- czynniki środowiskowe $\rightarrow$ wsparcie emocjonalne i systemowe,

- cechy osobowości stymulujące działanie $\rightarrow$ motywacja przedsiębiorcza (pasja, siła woli, marzenia, inicjatywa) oraz intencje przedsiębiorcze,

- czynnik losowy $\rightarrow$ pojawiające się w otoczeniu sposobności/okazje,

- myślenie twórcze,

- aktywność własna $\rightarrow$ działania przedsiębiorcze.

Z perspektywy prowadzonego wywodu wymienione czynniki można podzielić na trzy (niezupełnie rozłączne) grupy:

- czynniki kognitywne, związane ze sposobem myślenia (zdolności ogólne, umiejętność dostrzegania okazji, motywacja przedsiębiorcza i intencje przedsiębiorcze ${ }^{2}$, myślenie twórcze),

- czynniki energii zewnętrznej (wsparcie emocjonalne i systemowe, pojawiające się w otoczeniu sposobności/okazje),

- czynnik behawioralny - działania przedsiębiorcze (aktywność własna - praktyka, doświadczenie).

Taki podział unaocznia kardynalne znaczenie sposobu myślenia, mającego determinujący wpływ na faktyczną aktywność przedsiębiorczą.

\section{Modelowe typy przedsiębiorców}

Przyjmując, że krytyczne dla rozwoju przedsiębiorczości (jak i dla rozwoju innych ludzkich atrybutów) są dwie zbiorcze składowe: predyspozycje osobnicze (geny/potencjał wewnętrzny) oraz bodźce środowiskowe (wpływ indywidualnego i systemowego otoczenia zewnętrznego), można wyróżnić cztery modelowe typy przedsiębiorców (rycina 2).

\footnotetext{
${ }^{1}$ Zmiana liczby determinant jest efektem pracy autora nad rozwojem swojej koncepcji.

${ }^{2}$ Pojęcie intencji przedsiębiorczych bywa definiowane na wiele sposobów. W artykule przyjęto, że jest to „świadomy stan umysłu wyprzedzający działanie” (Shook, Priem, McGee, 2003). Intencje przedsiębiorcze stanowią pierwszą fazę działania przedsiębiorczego, po której następuje kolejno: poszukiwanie możliwości biznesowych, podejmowanie decyzji o założeniu firmy i - w końcu - podjęcie działań służących uruchomieniu firmy (Shook, Priem, McGee, 2003).
} 
Przedsiębiorcy potencjalni (A) to ci, którzy posiadają predyspozycje osobowościowe adekwatne do wymogów prowadzenia działalności przedsiębiorczej, ale nie są one doceniane ani wspierane przez otoczenie, w którym funkcjonują. W skład tej grupy wchodzą m.in. kobiety wychowywane tradycyjnie, uczone od małego "grzeczności” („dziewczynce nie wypada”, „siedź, aż cię znajdą”, „pokorne cielę dwie matki ssie” itd.), co skutecznie podcina ich zapędy do aktywnego kreowania świata - przynajmniej, nim dojrzeją (nie tylko dorosną).

Przedsiębiorcy faktyczni („urodzeni”) (B) to ci, których przedsiębiorcze predyspozycje zostały przez otoczenie docenione i wsparte, dzięki czemu podejmują działalność przedsiębiorczą. Trzeba tu zaznaczyć, że choć wielu self-made manów lubi podkreślać, że do wszystkiego doszło samodzielnie, zazwyczaj i oni w momencie (przed)startowym otrzymali ważne (z perspektywy czasu, choć w danym momencie obiektywnie często niewielkie) wsparcie: np. kontakt (adres, nazwisko, referencje), dostęp do komputera czy garażu, pierwsze sto dolarów itp.

Przedsiębiorcy wyuczeni („ewolucyjni”) (C) to ci, których potencjał genetyczny wymagał wzmocnienia i dzięki silnej motywacji wewnętrznej oraz stymulacji otoczenia rozwinęli swój talent przedsiębiorczy.

Natomiast mianem nie-przedsiębiorców (D) określono tych, których słabe genetyczne predyspozycje przedsiębiorcze nie zostały rozwinięte w wyniku działań własnych ani stymulacji otoczenia, w związku z czym pozostały nieaktywne.

Zaprezentowany na rycinie 2 modelowy podział przedsiębiorców ma charakter wyłącznie poznawczy: wskazuje możliwe, odmienne drogi dochodzenia do efektu (aktywność przedsiębiorcza) w odpowiedzi na odmienne zestawy predyspozycji i działań środowiskowych (form wsparcia) aktywujących działalność przedsiębiorczą. Mogą to być działania o bardzo zróżnicowanym charakterze, w zależności od rodzaju deficytu i jego siły/natężenia: od budujących poczucie własnej wartości i sprawstwa (przedsiębiorcy potencjalni) do „twardej” wiedzy z zakresu ekonomii, finansów i zarządzania (przedsiębiorcy „ewolucyjni”).

Waga problemu jest duża, co unaocznia odniesienie zaprezentowanego modelowego podziału przedsiębiorców do rozkładu normalnego. Nazywany też krzywą Gaussa, rozkład normalny ilustruje częstość (prawdopodobieństwo) występowania wartości zmiennej w badanej populacji, np. wzrostu albo poziomu inteligencji wśród ludzi. Pokazuje on, że wynik bliski średniej dotyczy największej liczby obserwacji (tu: osób), a im dalej od średniej, tym mniejsza liczba osób osiąga dany wynik (por. ryc. 3.).

Ponieważ rozkłady liczebności różnych cech pomiarów fizycznych, biologicznych i psychologicznych, w tym inteligencji mierzonej testami IQ, mają stwierdzony rozkład normalny, można przez analogię (por. Surma, 2010: 31-38) przyjąć, że dotyczyłoby to również rozkładu talentu przedsiębiorczego, ze szczególnym naciskiem na wyodrębnioną powyżej grupę czynników kognitywnych, związanych ze sposobem myślenia. Jeśli tak, to oznaczałoby to, że predyspozycje genetyczne związane z talentem przedsiębiorczym zaledwie $15,8 \%$ społeczeństwa są na wysokim i bardzo wysokim poziomie (margines, skrajność, ekstrema), tyle samo jest osób mających te predyspozycje na niskim i bardzo niskim poziomie, a większość ludzi $(68,2 \%)$ ma talent przedsiębiorczy na poziomie przeciętnym. Z ekonomii wiadomo, że największy zwrot otrzymuje się z inwestycji zasobów wysokiej jakości, które wymagają niewielkich nakładów umożliwiających ich wykorzystanie. 
Rycina 2. Typy przedsiębiorców

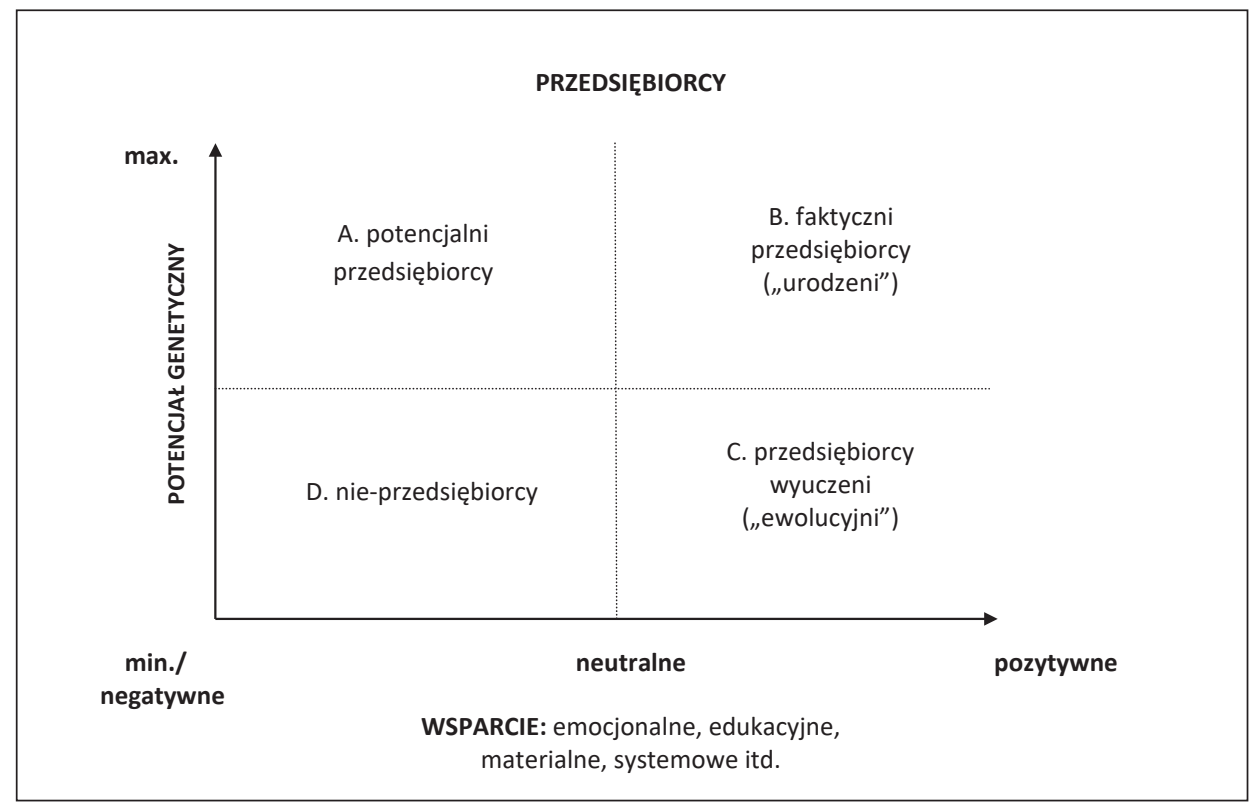

Źródło: opracowanie własne

Rycina 3. Rozkład normalny - częstość występowania wartości zmiennej w badanej populacji

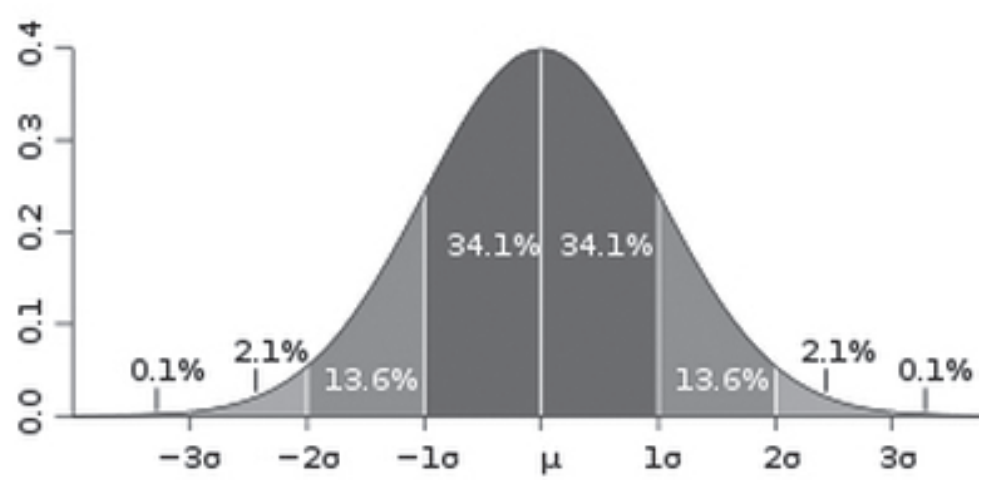

Źródło: Naukowiec.org (2019)

Niemniej jednak oparcie aktywności przedsiębiorczej ${ }^{3}$ na nieco ponad 1/6 społeczeństwa byłoby nieuzasadnionym marnotrawstwem, co potwierdzają wyniki wielu badań z obszaru neuronauk.

\footnotetext{
${ }^{3}$ Rozumianej szeroko, nie tylko jako akt prowadzenia własnej firmy, ale także jako sprawne zarządzanie sobą w życiu zawodowym i osobistym, które stanowi potencjalne źródło czynników utrudniających, ułatwiających, bądź uniemożliwiających czynne uczestnictwo w życiu społecznym, a we współczesnym świecie coraz trudniej je oddzielić od pracy.
} 
Odpowiedź neuronauk: plastyczność mózgu i tryby myślenia

Do lat 90. XX w. rozpowszechnione było- nawet wśród naukowców - przekonanie o tym, że nowe komórki nerwowe w mózgu powstają jedynie w okresie prenatalnym. Pod koniec lat 90. XX w. P. Eriksson z zespołem wykazał, że neurogeneza, czyli wytwarzanie nowych neuronów, dokonuje się także w dorosłym, ludzkim mózgu (konkretnie: w hipokampie), a wzbogacone środowisko życia, umiarkowana aktywność fizyczna oraz wysiłek intelektualny są kluczowymi determinantami ich proliferacji (rozmnażania) (Eriksson i in., 1998). Te dość rewolucyjne wnioski zainspirowały wielu naukowców do dalszych badań. Głośnym echem odbiło się badanie przeprowadzone przez E. Maguire z zespołem w środowisku londyńskich taksówkarzy, których praca (niewspomagana wówczas nawigacją satelitarną) wymagała zapamiętywania bardzo licznych i złożonych tras oraz lokalizacji. Okazało się, że wielkość hipokampów taksówkarzy była wprost proporcjonalna do liczby lat pracy w tym zawodzie (Maguire i in., 2000). To badanie, jak i wiele kolejnych nim zainspirowanych, dowiodło, że mózg można i należy trenować jak mięśnie, a więc, aby osiągnąć założone efekty (tu: wykształcić myślenie i zachowania przedsiębiorcze) należy pożądane myśli i zachowania wielokrotnie powtarzać (koncepcja 10 tys. godzin Gladwella, 2010) - aż staną się zautomatyzowane/nawykowe. Nie należy przy tym zaprzestawać wysiłków, gdyż wraz z zaniechaniem ćwiczeń wypracowane efekty cofają się, a przynajmniej ulegają osłabieniu, co dowiodło m.in. badanie przeprowadzone wśród żonglerów (Draganski et al., 2004). Jak to podsumował D. Eagleman, amerykański neurofizyk: „Jedną z najbardziej imponujących właściwości mózgu - szczególnie ludzkiego - jest jego elastyczność" (tj. zdolność dopasowywania układu nerwowego do konkretnego zadania), "dzięki czemu może posiąść niemal każdą umiejętność, która jest od niego wymagana" (Eagleman, 2012: 93).

Co więcej, mózg może się zmieniać pod wpływem dwóch grup bodźców: doświadczeń oraz działań czysto umysłowych: od medytacji po terapię poznawczo-behawioralną (Davidson, Begley, 2013: 215). Dlatego, choć potencjał genetyczny ma znaczenie, nie jest jednak determinujący: plastyczność mózgu wskazuje na kluczową rolę wsparcia i działania w rozwoju myślenia i działań przedsiębiorczych - także u osób dorosłych. W odniesieniu do istoty wywodu oznacza to, że odpowiednie działania, tzn. dobrane osobniczo i ukierunkowane na korygowanie zdiagnozowanych niedostatków w poszczególnych składowych talentu przedsiębiorczości, powinny skutkować istotnym wzrostem liczby osób przedsiębiorczych w społeczeństwie.

Ponieważ wśród składowych przedsiębiorczości postrzeganej jako talent istotną grupę stanowią czynniki kognitywne, dla rozwoju postaw i działań przedsiębiorczych kluczowe jest rozróżnienie trybów myślenia. Metaanalizy badań przeprowadzonych nad mózgiem wykazały, że człowiek myśli w dwóch trybach: świadomym i pozaświadomym (nieświadomym, podświadomym), przy czym ów podział odwołuje się do istoty funkcjonowania trybów, a nie ich umiejscowienia w mózgu. Myślenie szybkie i automatyczne (tzw. „system 1"), dokonuje się bez wysiłku lub z niewielkim wysiłkiem, nie ma przy nim poczucia świadomej kontroli; mieszczą się w nim myślenie intuicyjne (fachowe i heurystyczne) oraz automatyczne formy aktywności umysłowej (percepcja, pamięć). Natomiast myślenie wolne (tzw. „system 2”) wymaga skupienia uwagi; jego działanie wiąże się z subiektywnym poczuciem koncentracji, swobodnego wyboru i świadomego działania (Kahneman, 2012). 
Myślenie „systemem 1” jest szybkie dzięki zautomatyzowaniu procesów myślenia i działania. Co ważne, ten automatyzm w znacznej części jest wrodzony: zakodowany w genach, uwarunkowany ewolucyjnie i kulturowo (Diamond, 1996; Nisbett, 2015), ale może być też nabyty w wyniku świadomych ćwiczeń (jak u wspomnianych powyżej taksówkarzy), bądź pozaświadomych bodźców, generowanych przez otoczenie. Refleksyjne myślenie „systemem 2” włącza się dopiero wtedy, gdy „system 1” nie zna odpowiedzi na pytanie, ponieważ np. wymaga ono skomplikowanych wyliczeń lub gdy interpretowane zdarzenie jest sprzeczne ze zbudowanym w umyśle modelem rzeczywistości (Kahneman, 2012). Dlatego skuteczna edukacja dla przedsiębiorczości powinna się koncentrować na wytwarzaniu i wzmacnianiu automatyzmów przedsiębiorczego myślenia (i działania).

\section{Torowanie, ramowanie i zakotwiczenie a libertariański paternalizm}

R. Thaler, laureat Nagrody Banku Szwedzkiego im. Alfreda Nobla z 2017 r., został uhonorowany tym potocznie nazywanym Noblem z ekonomii za wkład w ekonomię behawioralną w obszarze psychologii podejmowania decyzji. W książce napisanej wraz z Cassem Sunsteinem pt. Impuls. Jak podejmować właściwe decyzje dotyczace zdrowia, dobrobytu i szczęścia (2017) wychodzi on od zdefiniowania „libertariańskiego paternalizmu” - pozornego oksymoronu (czyli wyrażenia sprzecznego wewnętrznie). Argumentację opiera na stwierdzeniu, że nie ma czegoś takiego, jak neutralny projekt, gdyż każdy projekt jest efektem pewnej architektury wyboru; dlatego z punktu widzenia maksymalizacji efektów indywidualnych i globalnych należy skoncentrować się na takim konstruowaniu architektury wyboru, by skłaniała ludzi do podejmowania decyzji dla nich lepszych, korzystniejszych (bardziej racjonalnych). Człon „libertarianizm” odnosi się więc do faktycznej wolności wyboru - w opozycji do zakazów lub nakazów, natomiast „paternalistyczny” dotyczy tworzenia „impulsów”4, które będą odpowiednio ukierunkowywać te decyzje. Albowiem „umieszczenie owoców na wysokości wzroku”, co zwiększa częstotliwość sięgania po nie - a są zdrowe - „jest impulsem. Zakaz niezdrowego żywienia nim nie jest” (Thaler, Sunstein, 2017: 16). Thaler stawia grubą linię demarkacyjną między ekonami (którzy zawsze myślą racjonalnie, czyli „systemem 2”) a ludźmi, którzy gros decyzji podejmują w zautomatyzowanym trybie szybkim, zawierającym cały wachlarz błędów poznawczych. Koncentruje się na tych drugich (pierwsi są tworem teoretycznym).

Wśród rozlicznych błędów poznawczych szczególnie istotny jest efekt torowania (priming effect), oparty na mechanizmach skojarzeń. Najczęściej dotyczy on wyrazów i pojęć (np. idea PICIA toruje ideę WODY) (Kahneman, 2012: 73), ale można torować także emocje i działania, co w swoim klasycznym już eksperymencie ${ }^{5}$ wykazał J. Bargh z zespołem (Bargh, Chen, Burrows, 1996): przemierzenie korytarza (co było drugim zadaniem eksperymentu) zajmowało więcej czasu osobom, które w zadaniu pierwszym układały „rozsypanki” z wyrazów kojarzących się ze starością (ale samo słowo „starość” nie padło, więc $w$ analizowanym przypadku torowanie dokonywało się pozaświadomie). Literatura przedmiotu dostarcza bogactwa fascynujących badań poświęconych torowaniu.

${ }^{4} \mathrm{~W}$ języku nudge oryginalnie użyte przez Thalera oznacza trącenie łokciem, szturchnięcie, ale tłumaczone jest jako impuls, zachęta, ewentualnie przynaglenie.

${ }^{5}$ Tak zwany efekt Florydy - Floryda, ze względu na swoje walory klimatyczne, stała się ulubionym miejscem zamieszkania amerykańskich emerytów. 
W kontekście prowadzonego wywodu warto odwołać się do rezultatu badania statystycznych prawidłowości przeprowadzanego w USA w 2000 r. referendum nad zwiększeniem finansowania szkolnictwa: znacząco częściej zwiększenie finansowania dla szkół popierali wyborcy w tych okręgach, w których lokale wyborcze umieszczono w szkołach (Berger, Meredith, Wheeler, 2008).

Nieco podobnym do torowania błędem poznawczym jest ramowanie (framing), czyli efekt kontekstu sytuacyjnego. Jak pokazują eksperymenty, ludzie (w tym także eksperci) znacząco odmiennie reagują na taką samą pod względem treściowym informację w zależności od sytuacji: sposobu jej przedstawienia i postrzegania. Na przykład pacjenci są zdecydowanie bardziej przestraszeni, gdy dowiadują się od lekarza, że w wyniku operacji dziesięciu na stu pacjentów zmarło, niż gdy zostaną poinformowani, że w dziewięćdziesięciu przypadkach na sto operacja się powiodła - mimo że treść przekazu jest przecież taka sama (za: Thaler, Sunstein, 2017: 53).

Zakotwiczenie (anchoring effect) dotyczy szacowania niewiadomej wielkości w sytuacji, gdy uprzednio została podana jakakolwiek (tzn. miarodajna lub nie) wartość liczbowa. Ponieważ każdy komunikat, poza odrzuconymi natychmiast jako kłamstwo, w taki sam sposób wpływa na system skojarzeniowy (Kahneman, 2012: 173), w zależności od wartości liczbowej kotwicy, szacunki badanego zjawiska mogą różnić się znacząco - skutkując diametralnie różnymi decyzjami - niejednokrotnie bardzo niepokojącymi. Na przykład niemieccy sędziowie o 15-letnim doświadczeniu zawodowym, po przeczytaniu opisu dotyczącego kobiety, która została przyłapana w sklepie na kradzieży, wykonywali rzut specjalnie obciążoną kostką. Okazało się, że ci, którym wypadła liczba 9, ferowali wyroki więzienia średnio wyższe (8 miesięcy), niż ci, którym wypadły w rzucie kostką trójki - średnio 5 miesięcy! (Englich, Mussweiler, Strack, 2006).

Thalerowski „impuls” wykorzystuje więc potencjał, który kryje się w zasygnalizowanych powyżej (i innych) błędach poznawczych. Wiedząc, że ludzie (w odróżnieniu od ekonów) myślą głównie w trybie szybkim, zautomatyzowanym, poddającym się torowaniu, ramowaniu, kotwiczeniu itd., wykorzystuje te zjawiska do sugerowania/podsuwania lepszych (zdrowszych, tańszych, bezpieczniejszych itd.) wyborów. Thaler i Sunstein (2017) opisują te możliwości w odniesieniu do inwestowania, kredytowania, systemu ubezpieczeń, dawstwa organów itp., ale równie dobrze można ten sposób myślenia odnieść do implementacji korzystnego, tj. sprzyjającego jej rozwojowi, edukowania przedsiębiorczości.

\section{Dyskusja i wnioski dla edukacji dla przedsiębiorczości}

Postrzeganie przedsiębiorczości jako talentu uzmysławia powszechność jego występowania (choć na zróżnicowanym poziomie), a zatem też możliwość jego powszechnego rozwijania za pomocą dopasowanych do czasu, potrzeb i sytuacji narzędzi. Koresponduje zarazem z koncepcją przedsiębiorczości ewolucyjnej, która zakłada, że każdy (pracownik) może stać się przedsiębiorcą, pod warunkiem odpowiedniego doskonalenia potrzebnych umiejętności. Dorobek neuronauk wspiera powyższe wnioski rezultatami badań, w szczególności w obszarze plastyczności mózgu, natomiast ekonomia behawioralna wskazuje drogi racjonalizowania decyzji ludzi - w odróżnieniu od ekonów - przez wykorzystanie popełnianych przez nich błędów myślenia do konstruowania architektury wyborów opartej na starannie dobranych „impulsach”. 
Z perspektywy prowadzonego wywodu wiedza na temat trybów myślenia, a w szczególności stwierdzenie, że myślenie szybkie, zautomatyzowane jest dla ludzi opcją domyślną, wskazuje na konieczność pracy nad wykształceniem pożądanych automatyzmów dotyczących przedsiębiorczości, $\mathrm{z}$ naciskiem na przedsiębiorcze myślenie. Ponieważ wykształcenie i rozwój talentu wymagają długotrwałego treningu - zgodnie z koncepcją M. Gladwella około 10 tys. godzin (Gladwell, 2010), edukację tę zacząć należy jak najwcześniej. Ponieważ temat jest szeroki, w tym miejscu można się odnieść jedynie do kilku kwestii.

Przede wszystkim warto torować samo pojęcie przedsiębiorczości od najmłodszych klas/przedszkola, nazywając tak (i w ten sposób chwaląc, co stanowi dodatkowe wzmocnienie) zachowanie dziecka, np. gdy z własnej inicjatywy rozdało kolegom kredki, by szybciej zacząć rysować - to nie jest tylko uczynność! Choć pojęcie przedsiębiorczości wydaje się abstrakcyjne, oznacza po prostu „wziąć przed się” (przed siebie, czyli w swoje ręce, nie czekając, aż dostaniemy od innych), co już jest łatwe do zrozumienia. Także prowadząc zajęcia, w których odwołujemy się do ważnych postaci, warto wyeksponować ich przedsiębiorczość, np. Maria Skłodowska-Curie jest wzorcem naukowca, który by zrealizować swoje marzenia i dążenia, musiał wykazać się przedsiębiorczością na wielu etapach swojej kariery, choćby wyjeżdżając na studia na Sorbonę, doprowadzając do powstania Instytutu Radowego czy organizując szkołę dla swoich córek (dostępne nie spełniały jej oczekiwań), w której wykładał sam Albert Einstein.

Natomiast świetnym miejscem dla ramowania i kotwiczenia są ściany w klasach, na których zawiesza się prace uczniów i materiały dydaktyczne. By świadomie wykorzystać tę moc, ponieważ to, co wpada w oko, właśnie nas toruje/ramuje/zakotwicza, można eksponować tam np. zdjęcia osób, które dzieci podziwiają, chciałyby naśladować itp., często nazywanych autorytetami. Dość łatwo udowodnić, że tym, co dzieci w nich naprawdę podziwiają, jest właśnie przedsiębiorczość - skuteczność pokierowania swoim życiem w pożądanym kierunku. Dodatkowo, dzieci musiałyby takie postacie wyszukać, uzasadnić ich wybór, a w trakcie prezentacji w klasie łatwo można by je „szturchać” (w znaczeniu nudge, oczywiście), wskazując kluczową rolę przedsiębiorczości w ich osiągnięciach i konkretne jej przejawy. Absolutnie niedocenianym, a wspaniale opisanym przykładem przedsiębiorczości w literaturze (uważanej za „romansową" w dodatku) jest Przeminęło $z$ wiatrem Margaret Mitchell. Choć na pierwszy plan wydaje się wychodzić wątek miłosny (i to on został szczególnie wyeksponowany w ekranizacji), de facto jest to opowieść o kobiecie przedsiębiorczej, funkcjonującej w czasach, gdy samodzielność i niezależność kobiet były pustymi pojęciami. Omawiając z dziećmi lektury (czy dokonując wyboru lektur nieobowiązkowych), warto wyłuskać ze zwyczajowych płaszczyzn analizy także tę przedsiębiorczą. Można ją znaleźć w zasadzie w każdej lekturze, aczkolwiek nie u każdego bohatera.

Oczywiście równie ważne jest ćwiczenie przedsiębiorczości w działaniu i to jest kolejny obszar wykorzystywania „impulsów”. T. Walker, autor książki Fińskie dzieci ucza się najlepiej, porównuje swoje doświadczenia amerykańskiego nauczyciela z wyzwaniami dwóch lat pracy w szkole fińskiej. Opisuje on m.in., jak podczas przygotowań do roku szkolnego, jeszcze zanim poznał swoich uczniów, postanowił, że w ramach projektu klasowego zbierze razem $\mathrm{z}$ nimi pieniądze dla młodych fińskich paraolimpijczyków, a potem opiszą ich przeżycia na swoich blogach i może w efekcie zapoczątkują narodową dyskusję nad problemami finansowymi, z którymi muszą się zmagać niepełnosprawni sportowcy. Już nawet zorganizował spotkania z przedstawicielami fińskiego komitetu paraolimpijskiego, po czym okazało się, że dzieci w ogóle nie podzieliły jego wizji, więc z braku ich 
motywacji projekt nie został zrealizowany. Gdy nauczyciel przeanalizował swój błąd, organizację tzw. szkoły biwakowej niemal w całości oddał w ręce uczniów, wysyłając tylko „impulsy”, ukierunkowujące ich działania (np. przydatność zorganizowania kiermaszu, by zarobić potrzebne na wyjazd fundusze, czy konieczność założenia konta klasowego w banku, by dokonywać przelewów). Szkoła biwakowa doszła do skutku, mimo różnych perturbacji, które pojawiły się, ponieważ jednak nie jest łatwo wypracować zadowalający wszystkich konsensus, co też stanowiło pożyteczną naukę (Walker, 2017; 86-91). Choć Walker tak tego nie nazwał, tryb organizacji projektu zastosowany dla szkoły biwakowej był spójny z założeniami „libertariańskiego paternalizmu” Thalera: uczniowie mieli w zasadzie wolny wybór, ale nauczyciel, komentując kolejne wady i zalety, skłonił uczniów do dokonywania wyborów spośród bardziej korzystnych opcji.

Niewątpliwie, edukacja dla przedsiębiorczości oparta na dorobku ekonomii behawioralnej wymaga modyfikacji stylów i metod nauczania. Stanowi to pewne wyzwanie, niemniej jednak kształtowanie postaw i aktywności przedsiębiorczych jedynie/głównie w ramach lekcji przedsiębiorczości - choćby najlepiej zorganizowanych i prowadzonych - jest niewystarczające: przede wszystkim z powodu skromnych ram czasowych, głęboko niewystarczających do wykształcenia automatyzmów mentalnych, tj. przedsiębiorczego postrzegania świata, za którym dopiero może pójść działanie.

Rozwój świata opiera się na przedsiębiorczości, a dokonania neuronauk wskazują wiele owocnych obszarów jej stymulowania. Należy je na bieżąco śledzić, gdyż są one istotnie zmienne w czasie: nieustannie pojawiają się nowe badania - także te obalające aktualny stan wiedzy (jak odkrycie plastyczności mózgu dorosłego człowieka). Pomimo tych ograniczeń, dokonania neuronauk powinny stanowić obowiązkową perspektywę (choć komplementarną) badań charakterystyk osobowych i zachowań ludzkich, w tym przypadku - przedsiębiorczych.

Literatura

References

Bargh, J.A., Chen, M., Burrows, L. (1996). Automaticity of Social Behavior: Direct Effects of Trait Construct and Stereotype Activation on Action. Journal of Personality and Social Psychology, 71(2), 230-244. Pozyskano z: https://www.psychologytoday.com/files/attachments/5089/barghchenburrows1996.pdf

Berger, J., Meredith, M., Wheeler, S.Ch. (2008). Proceedings of the National Academy of Sciences, 105(26), 8846-8849. Pozyskano z: https://www.researchgate.net

Davidson, R.I., Begley, S. (2013). Życie emocjonalne mózgu. Kraków: Wydawnictwo Uniwersytetu Jagiellońskiego.

Dąbrówka, A., Geller, E., Turczyn, R. (1993). Słownik synonimów. Warszawa: MCR.

Diamond, J. (1996). Trzeci szympans. Warszawa: PIW.

Draganski, B., Gaser, C., Busch, V., Schuierer, G., Bogdahn, U., May, A. (2004). Neuroplasticity: changes in grey matter induced by training. Nature, 427(6972), 311-312.

Eagleman, D. (2012). Mózg incognito. Wojna domowa w twojej głowie. Warszawa: Carta Blanca.

Internetowa encyklopedia PWN, hasło: iloraz inteligencji. (2019, 7 września). Pozyskano z: https://encyklopedia.pwn.pl/haslo/iloraz-inteligencji;3914179.html

Englich, B., Mussweiler, Th., Strack, F. (2006). Playing Dice With Criminal Sentences: The Influence of Irrelevant Anchors on Experts' Judicial Decision Making. Personality and Social Psychology Bulletin, 32(2), 188-200. Pozyskano z: http://www.eucim-te.eu/data/dppsenglich/File/PDFSStudien/ PSPB_32(1).pdf 
Eriksson, P.S., Perfilieva, E., Björk-Eriksson, T., Alborn, A.-M., Nordborg, C., Daniel, A. Peterson, D.A., Gage, F.H. (1998). Neurogenesis in the Adult Human Hippocampus. Nature Medicine, 4, 1313-1317.

Gladwell, M. (2010). Poza schematem. Sekrety ludzi sukcesu. Kraków: Znak.

Hornowski, B. (1986). Rozwój inteligencji i uzdolnień specjalnych. Warszawa: Wydawnictwa Szkolne i Pedagogiczne.

Jamka, B. (2014). Wzrost innowacyjności organizacji poprzez rozwój przedsiębiorczości jako talentu. W: E. Skrzypek (red.), Wplyw wiedzy na sukces organizacji w nowej gospodarce. Lublin: UMCS, 79-92.

Kahneman, D. (2012). Pułapki myślenia. O myśleniu szybkim i wolnym. Poznań: Media Rodzina.

Maguire, E.A., Gadian, D.G., Johnsrude, I.S., Good, C.D., Ashburner, J., Frackowiak, R.S. J. i Frith, C.D. (2000). Navigation-related structural change in the hippocampi of taxi drivers. Proceedings of the National Academy of Sciences, 97(8), 1398-1403.

Nisbett, R.E. (2015). Geografia myślenia. Dlaczego ludzie Wschodu i Zachodu myśla inaczej?. Sopot: Smak Słowa.

Naukowiec.org. (2019, 19 kwietnia). https://www.naukowiec.org/wiedza/statystyka/rozklad-normalny-rozklad-gaussa_710.html

Shook, C.L., Priem, R.L., McGee, J.E. (2003). Venture Creation and the Enterprising Individual: a Review and Synthesis. Journal of Management, 29(3), 379-399.

Strelau, J. (1997). Inteligencja człowieka. Warszawa: Wydawnictwo Akademickie Żak.

Surma J. (2010). Rola analogii w podejmowaniu decyzji w zarzadzaniu strategicznym małymi i średnimi przedsiębiorstwami. Warszawa: Oficyna Wydawnicza Szkoła Główna Handlowa w Warszawie.

Tannenbaum, A.J. (1984). Gifted children: Psychological and educational perspectives. New York: MacMillan.

Thaler, R.H., Sunstein C.R. (2017). Impuls. Jak podejmować właściwe decyzje dotyczące zdrowia, dobrobytu i szczęścia. Poznań: Zysk i S-ka.

Walker, T.D. (2017). Fińskie dzieci ucza się najlepiej. Co możemy zrobić, by nasze dzieci były szczęśliwsze, wierzyły w siebie i lubiły szkołę? Kraków: Wydawnictwo Literackie.

Wissema, J.G. (2005). Technostarterzy - dlaczego i jak?. Warszawa: PARP.

Beata Jamka, dr hab. nauk ekonomicznych, naukowiec niezależny, Warszawa, Polska, profesor, wieloletni pracownik Szkoły Głównej Handlowej w Warszawie, stypendystka Fundacji Jurzykowskiego (USA), profesor nadzwyczajny Uczelni Łazarskiego, wykładowca i promotor Studiów Podyplomowych Zarządzania Zasobami Ludzkimi w Organizacji KNoP/SGH. Autorka licznych publikacji naukowych, m.in monografii Czynnik ludzki we wspótczesnym przedsiębiorstwie: zasób czy kapitał? Od zarzadzania kompetencjami do zarządzania różnorodnością (2011), Razem. Ku zmianie paradygmatu gospodarowania (2017) i HR na zakręcie. Zarzadzanie przez pomiar czy aktywacja kreatywności? (2019). Jej najnowsze zainteresowania naukowe ulokowane są na styku neuronauk i zarząazzania potencjałem ludzkim (kreatywność, innowacyjność, przedsiębiorczość, efektywność); obejmują także alternatywne paradygmaty gospodarowania.

Beata Jamka, habilitated doctor in economics/management, independent researcher, long-time employee of the Warsaw School of Economics, scholarship holder of the Jurzykowski Foundation (USA), associate professor at Lazarski University, lecturer and supervisor of Postgraduate Studies in Human Resources Management at the Warsaw School of Economics. Author of numerous publications, including the latest monographs: Human factor in contemporary enterprise: resource or capital? From competency management to diversity management (2011), Together. Towards a change in the paradigm of economics (2017) and HR at the turn. Management by measurement or creativity activation? (2019). Her latest interests combine neuroscience and human potential management (creativity, innovation, entrepreneurship, efficiency); they also include alternative paradigms of economics.

ORCID: https://orcid.org/0000-0002-5703-0003

\author{
Adres/Address: \\ Warszawa, Polska \\ e-mail: beata.b.jamka@gmail.com
}

